\title{
Mercury concentrations in fish species caught at Mid-Atlantic Ridge hydrothermal vent fields
}

\author{
I. Martins*, V. Costa, F. M. Porteiro, A. Colaço, R. S. Santos \\ IMAR, DOP-Department of Oceanography and Fisheries, University of the Azores, 9901-862 Horta, Azores, Portugal
}

\begin{abstract}
Concentrations of total mercury and methyl mercury were determined in muscle and liver samples of 8 fish species caught at the Menez Gwen, Lucky Strike and Rainbow hydrothermal vents (Mid-Atlantic Ridge). The species studied were Hydrolagus pallidus, H. affinis, Synaphobranchus kaupi, Epigonus telescopus, Mora moro, Antimora rostrata, Deania calceus and Etmopterus princeps. Median total mercury concentrations found in muscle tissue of the 8 species ranged between 0.6 and $1.9 \mathrm{\mu g} \mathrm{g}^{-1}$ wet weight and between 0.1 and $1.7 \mu \mathrm{g} \mathrm{g}^{-1}$ wet weight for liver tissue in 5 of the species. Differences in total mercury concentration in species caught at the different hydrothermal vents, comparisons between tissues and correlation with total length are described. In general, liver tissues present lower total mercury concentrations than muscle. Methyl mercury accumulated in fish from this study comprises, on average, $>80 \%$ of the total mercury. The total mercury concentrations found were higher than those previously published for deep-sea fish. These fish species were exposed to high levels of mercury, due not only to bioavailability of toxic and stable forms of mercury in the water, but also to predation on organisms exposed to this metal.
\end{abstract}

KEY WORDS: Mercury · Deep-sea fish $\cdot$ Mid-Atlantic Ridge $\cdot$ Lucky Strike $\cdot$ Menez Gwen $\cdot$ Rainbow

\section{INTRODUCTION}

The deep sea is a cold, dark and uniform environment, with low fish biomass, much of which is highly adapted for life in a food-poor environment (Gordon 2001). In contrast, at hydrothermal vents, there is high local productivity (Gage \& Tyler 1991). The high concentration of biomass provides an important food source for both predatory and scavenging species, including fish that are regularly seen among and around hydrothermal communities (Biscoito et al. 2003). The combination of low $\mathrm{O}_{2}$, high levels of $\mathrm{H}_{2} \mathrm{~S}$ and heavy metals (e.g. $\mathrm{Zn}, \mathrm{Cu}, \mathrm{Cr}$ and $\mathrm{Hg}$ ) gives the vent environments a highly toxic character for most marine animals (Childress \& Fisher 1992). Mercury is the only metal that consistently biomagnifies through the food chain, i.e. predators accumulate higher tissue concentrations than their prey (Monteiro et al. 1996). Many deep-sea fish tend to be top predators and to feed at higher trophic levels than their shelf counter- parts; thus, the potential for accumulation of trace metals (particularly mercury) is higher in deep-water species (Cronin et al. 1998). Lucky Strike and Menez Gwen fields (Mid-Atlantic Ridge) showed an absence of endemic-associated ichthyofauna. However, some deep-sea fishes living in the neighbourhood of hydrothermal vents may feed on animals from the vent community (Saldanha 1994, Marques \& Porteiro 2000). Therefore, it becomes important to evaluate whether fish caught in the vicinity of vent fields present higher mercury concentrations than fish that live further away from hydrothermal influence.

The aim of the present study was to assess the concentration of total mercury in some fish species caught at the Mid-Atlantic Ridge (MAR) hydrothermal vent fields Menez Gwen, Lucky Strike and Rainbow. The results were compared with data from literature for species with similar diets. Additionally, samples from Epigonus telescopus and Mora moro, caught at the Azores archipelago, were analyzed for comparison. 
Table 1. Species name, habitat and prey (information collected from FishBase) and capture site of the fish species included in the present study ( $\mathrm{N}$ : number of individuals in each sample). Length is given as total length, except for Antimora rostrata and Mora moro from Azores (fork length)

\begin{tabular}{|c|c|c|c|c|c|c|}
\hline \multirow{2}{*}{$\begin{array}{l}\text { Species } \\
\text { (common name) }\end{array}$} & Habitat & Prey & Site & $\mathrm{N}$ & \multicolumn{2}{|c|}{ Length $(\mathrm{cm})$} \\
\hline & $\begin{array}{l}\text { Continental slopes and } \\
\text { down to deep-sea plains }\end{array}$ & $\begin{array}{l}\text { Mussels from hydrothermal vents } \\
\text { (Marques \& Porteiro 2000) }\end{array}$ & Lucky Strike & 8 & 116 & $89-130$ \\
\hline $\begin{array}{l}\text { Hydrolagus pallidus } \\
\text { (pallid rabbitfish) }\end{array}$ & $\begin{array}{l}\text { Eastern North Atlantic } \\
\text { continental slopes of Europe }\end{array}$ & Small fishes and invertebrates & Lucky Strike & 36 & 106 & $83-138$ \\
\hline \multirow[t]{3}{*}{$\begin{array}{l}\text { Synaphobranchus kaupi } \\
\text { (cutthroat-eel) }\end{array}$} & $\begin{array}{l}\text { Continental slope near the } \\
\text { upper limit of abyssal zone }\end{array}$ & $\begin{array}{l}\text { Decapoda, Natantia, amphipods, } \\
\text { but also fishes and cephalopods }\end{array}$ & Lucky Strike & 22 & 57 & $41-68.5$ \\
\hline & & & $\begin{array}{l}\text { Menez Gwen/ } \\
\text { Lucky Strike }\end{array}$ & 19 & 59.5 & $46.5-67.5$ \\
\hline & & & Menez Gwen & 50 & 56 & $42-100$ \\
\hline $\begin{array}{l}\text { Epigonus telescopus } \\
\text { (black cardinalfish) }\end{array}$ & $\begin{array}{l}\text { Soft bottoms, } \\
\text { non-territorial }\end{array}$ & $\begin{array}{l}\text { Small fishes and planktonic } \\
\text { invertebrates }\end{array}$ & Menez Gwen & 10 & 56 & $45-73$ \\
\hline $\begin{array}{l}\text { Mora moro } \\
\text { (common mora) }\end{array}$ & Upper continental slope & $\begin{array}{l}\text { Fishes, crustaceans, molluscs and } \\
\text { other invertebrates as well as food } \\
\text { of terrestrial origin }\end{array}$ & Menez Gwen & 16 & 57.5 & $46-68$ \\
\hline $\begin{array}{l}\text { Antimora rostrata } \\
\text { (blue antimora) }\end{array}$ & $\begin{array}{l}\text { Continental slope and } \\
\text { upper rise }\end{array}$ & Benthic invertebrates & Rainbow & 13 & 57 & $45-70$ \\
\hline \multirow[t]{2}{*}{$\begin{array}{l}\text { Deania calceus } \\
\text { (birdbeak dogfish) }\end{array}$} & $\begin{array}{l}\text { Outer continental and insular } \\
\text { shelves and upper slopes }\end{array}$ & $\begin{array}{l}\text { Pelagic bony fish, squid, octopus } \\
\text { and shrimp }\end{array}$ & $\begin{array}{l}\text { Menez Gwen/ } \\
\text { Lucky Strike }\end{array}$ & 10 & & $\begin{array}{c}81-109.5 \\
76-105\end{array}$ \\
\hline & & & Menez Gwen & 20 & 95 & \\
\hline \multirow[t]{2}{*}{$\begin{array}{l}\text { Etmopterus princeps } \\
\text { (lanter shark) }\end{array}$} & Continental slopes & $\begin{array}{l}\text { Teleosts, cephalopods and } \\
\text { crustaceans }\end{array}$ & $\begin{array}{l}\text { Lucky Strike } \\
\text { Menez Gwen/ }\end{array}$ & 68 & 54 & $33-57$ \\
\hline & & & Lucky Strike & 12 & 45 & $37-68$ \\
\hline
\end{tabular}

\section{MATERIALS AND METHODS}

Species studied. The species analysed were caught at Menez Gwen (MG: $37^{\circ} 50^{\prime} \mathrm{N}, 31^{\circ} 30^{\prime} \mathrm{W}$ ), Lucky Strike (LS: $37^{\circ} 17^{\prime} \mathrm{N}, 32^{\circ} 16^{\prime} \mathrm{W}$ ) and Rainbow (RB: $36^{\circ} 13^{\prime} \mathrm{N}, 32^{\circ} 22^{\prime} \mathrm{W}$ ) hydrothermal fields (Table 1), at ca. 800, 1750 and $2300 \mathrm{~m}$ depth, respectively. Several specimens were caught in an area between Menez Gwen and Lucky Strike (MG/LS) (37 $44^{\prime}$ N, $\left.32^{\circ} 05^{\prime} \mathrm{W}\right)$. Sampling was carried out during the summers of 1997 , 2000, 2001 and 2002 by the RV 'Arquipélago'. A bottom long-line was used, with 1000 hooks baited with salted sardine and mackerel. From each individual total length (TL) was recorded.

Muscle samples of Epigonus telescopus and Mora moro caught in Azorean waters ( $37^{\circ} 50^{\prime} \mathrm{N}, 25^{\circ} 30^{\prime} \mathrm{W}$ ), away from hydrothermal vent environments, were used for comparison.

Analysis. A sample of muscle was taken dorsally, directly posterior to the operculum, for mercury analysis. Samples of liver were also taken. The samples were placed in sealed bags, labelled and kept frozen $\left(-20^{\circ} \mathrm{C}\right)$. The analyses were performed on dry tissues by cold vapour atomic absorption spectrophotometry (Bacharach Coleman Model 50B). The proce- dure to release mercury from tissues is based on acid digestion of the samples, oxidation by permanganate, titration of excess permanganate and reduction to elemental mercury vapour. The method used to extract organic mercury did not permit speciation of organomercurials, but, since monomethyl mercury is the form normally found in biological samples (Horvat et al. 1988), it was assumed that organic mercury extracted was monomethyl mercury. The procedure involves extracting methyl mercury into toluene, as methyl mercuric bromide, followed by stripping of methyl mercury from toluene into thiosulphate. Samples were mineralised and digested as described by Monteiro (1996).

Analytical accuracy was checked using reference materials, provided by the National Research Council of Canada (dogfish muscle tissue, DORM-1 and DORM-2 and dogfish liver tissue DOLT-2). Good accuracy and precision of the analytical method were confirmed (Table 2). Detection limits for total mercury and methyl mercury were 0.006 and $0.012 \mu \mathrm{g} \mathrm{g}^{-1}$, respectively. Interference on sensitivity due to matrix and pre-treatment were assessed by the method of standard additions before the wet mineralisation digestion. Recoveries of added inorganic mercury averaged 
Table 2. Total and methyl mercury (MeHg) concentrations $\left(\mu \mathrm{g} \mathrm{g}^{-1}\right)$ in dogfish muscle (DORM-1 and DORM-2, provided by the National Research Council of Canada), and dogfish liver (DOLT-2) determined in the present study and certified values (n: number of samples analysed). Results present means $( \pm \mathrm{SD})$

\begin{tabular}{|llcc|}
\hline $\begin{array}{l}\text { Certified reference } \\
\text { material }\end{array}$ & Total Hg & MeHg \\
\hline $\begin{array}{l}\text { DORM-1 } \\
(\mathrm{n}=8)\end{array}$ & Certified & - & $0.73 \pm 0.06$ \\
DORM-2 & Present study & - & $0.63 \pm 0.05$ \\
$(\mathrm{n}=22)$ & Certified & $4.64 \pm 0.26$ & - \\
$\begin{array}{l}\text { DOLT-2 } \\
(\mathrm{n}=9)\end{array}$ & Present study & $4.57 \pm 0.12$ & - \\
& Certified & & \\
& Present study & $2.14 \pm 0.28$ & - \\
\hline
\end{tabular}

$85.8 \%(\mathrm{SD}=10.4, \mathrm{n}=7)$ for muscle tissue and $74.7 \%$ $(\mathrm{SD}=10.8, \mathrm{n}=3$ ) for liver. For methyl mercury, the average was $82 \%(\mathrm{SD}=9, \mathrm{n}=10)$ for muscle tissue.

Mercury concentrations are reported in micrograms per gram, converted to wet weight for comparison with other studies. As concentration of mercury did not follow a normal distribution and did not show homogeneity of variances, non-parametric analysis using the Kruskal-Wallis test was performed. Spearman's coefficient $\left(r_{S}\right)$ was calculated to determine the correlation between total mercury concentration and species total length. All tests were considered significant at $\mathrm{p} \leq 0.05$.

\section{RESULTS}

The total mercury concentrations measured in muscle and liver tissue of the fish analysed are presented in Table 3. Median total mercury concentrations varied from 0.6 to $1.9 \mathrm{\mu g} \mathrm{g}^{-1}$ in muscle, with the highest concentration in Etmopterus princeps from LS. Significant differences were found in total mercury concentrations between the muscle tissue of the 2 Hydrolagus species (Kruskal-Wallis, $\mathrm{p}=0.001$ ). Species captured at $>1$ site did not show significant differences in total mercury concentrations in muscle between sites (Synaphobranchus kaupi, Kruskal-Wallis, p = 0.06; Deania calceus and E. princeps, Kruskal-Wallis, $\mathrm{p}=0.20$ and $\mathrm{p}=$ 0.12 , respectively). The 2 shark species from the area MG/LS had statistically different mercury concentrations in muscle (Kruskal-Wallis, $\mathrm{p}=0.001$ ). No significant differences were detected between total mercury concentrations in muscle of Epigonus telescopus (Kruskal-Wallis, p = 0.22) and Mora mora (KruskalWallis, $p=0.93$ ), caught in hydrothermal vent fields and elsewhere in the Azores archipelago. In liver, median total concentrations varied from 0.1 to $1.7 \mu \mathrm{g}$ $\mathrm{g}^{-1}$, with highest concentrations in $S$. kaupi from MG.

For most of the species it is noteworthy that liver tissue presents statistically lower total mercury concentrations than muscle (Fig. 1) (Kruskal-Wallis; Hydrolagus pallidus, $\mathrm{p}=0.0002 ;$ Antimora rostrata, $\mathrm{p}=0.0001 ;$ Deania calceus from $\mathrm{MG}, \mathrm{p}=0.0000$ and from MG/LS, p = 0.0002), except for Mora moro (Kruskal-Wallis, $\mathrm{p}=0.08$ ). Synaphobranchus kaupi is

Table 3. Median total mercury concentrations and ranges in the muscle and liver tissue of the fish species used in the present study ( $\mu \mathrm{g} \mathrm{g}^{-1}$ wet weight) (n: number of samples analysed). MeHg (methyl mercury) results are expressed as a percentage of total mercury

\begin{tabular}{|c|c|c|c|c|c|c|c|}
\hline Species & Site & $\mathrm{n}$ & Total tissue & Hg median & Range & $\mathrm{n}$ & $\mathrm{MeHg}(\%)$ \\
\hline Hydrolagus affinis & Lucky Strike & 7 & Muscle & 1.4 & $1.0-2.2$ & 1 & 90 \\
\hline Hydrolagus pallidus & Lucky Strike & $\begin{array}{l}36 \\
12\end{array}$ & $\begin{array}{l}\text { Muscle } \\
\text { Liver }\end{array}$ & $\begin{array}{l}0.9 \\
0.3\end{array}$ & $\begin{array}{l}0.2-1.4 \\
0.1-1.05\end{array}$ & 2 & 81 \\
\hline Synaphobranchus kaupi & $\begin{array}{l}\text { Lucky Strike } \\
\text { Menez Gwen/Lucky Strike } \\
\text { Menez Gwen }\end{array}$ & $\begin{array}{r}21 \\
18 \\
46 \\
9\end{array}$ & $\begin{array}{l}\text { Muscle } \\
\text { Muscle } \\
\text { Muscle } \\
\text { Liver }\end{array}$ & $\begin{array}{l}0.6 \\
1.0 \\
0.6 \\
1.7\end{array}$ & $\begin{array}{l}0.1-2.2 \\
0.2-1.9 \\
0.1-2.0 \\
0.7-2.0\end{array}$ & $\begin{array}{l}- \\
2 \\
2\end{array}$ & $\begin{array}{l}- \\
98 \\
97\end{array}$ \\
\hline Epigonus telescopus & Menez Gwen & 10 & Muscle & 1.1 & $0.4-2.5$ & - & - \\
\hline Mora moro & Menez Gwen & $\begin{array}{r}16 \\
5\end{array}$ & $\begin{array}{l}\text { Muscle } \\
\text { Liver }\end{array}$ & $\begin{array}{l}1.2 \\
0.7\end{array}$ & $\begin{array}{l}0.6-2.1 \\
0.2-1.8\end{array}$ & - & - \\
\hline Antimora rostrata & Rainbow & $\begin{array}{l}13 \\
11\end{array}$ & $\begin{array}{l}\text { Muscle } \\
\text { Liver }\end{array}$ & $\begin{array}{l}1.1 \\
0.4\end{array}$ & $\begin{array}{l}0.6-1.5 \\
0.1-0.7\end{array}$ & - & - \\
\hline Deania calceus & $\begin{array}{l}\text { Menez Gwen/Lucky Strike } \\
\text { Menez Gwen }\end{array}$ & $\begin{array}{l}10 \\
10 \\
20 \\
13\end{array}$ & $\begin{array}{l}\text { Muscle } \\
\text { Liver } \\
\text { Muscle } \\
\text { Liver }\end{array}$ & $\begin{array}{l}1.0 \\
0.1 \\
1.2 \\
0.1\end{array}$ & $\begin{array}{r}0.5-2.0 \\
0.003-0.2 \\
0.6-2.5 \\
0.03-0.3\end{array}$ & - & - \\
\hline Etmopterus princeps & $\begin{array}{l}\text { Lucky Strike } \\
\text { Menez Gwen/Lucky Strike }\end{array}$ & $\begin{array}{l}68 \\
12\end{array}$ & $\begin{array}{l}\text { Muscle } \\
\text { Muscle }\end{array}$ & $\begin{array}{l}1.9 \\
1.7\end{array}$ & $\begin{array}{l}1.0-3.6 \\
1.0-2.1\end{array}$ & $\begin{array}{l}3 \\
-\end{array}$ & $\begin{array}{c}79 \\
-\end{array}$ \\
\hline
\end{tabular}




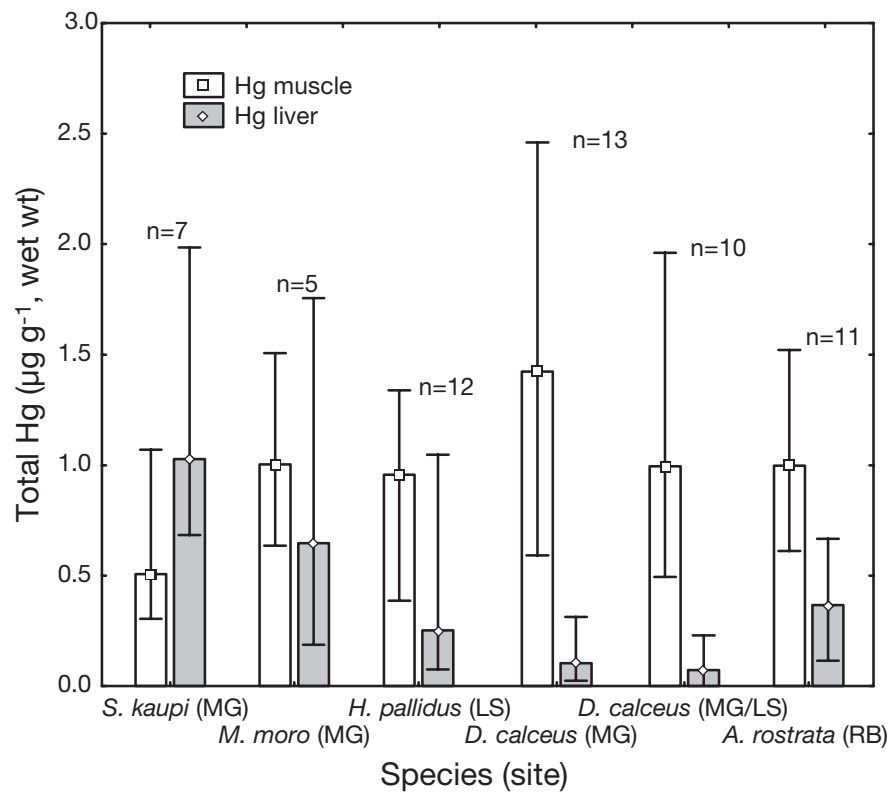

Fig. 1. Medians and ranges of total mercury concentration ( $\mu \mathrm{g} \mathrm{g}^{-1}$ wet wt) in muscle and liver tissues from the 5 species analysed (n: number of samples analysed)

the only species that showed higher total mercury concentrations in the liver (Kruskal-Wallis; $\mathrm{p}=0.05$ ) (Fig. 1).

Although only a few methyl mercury measurements were accomplished in this study, due to the small amounts of available dried samples, these results show that the bulk (>80\%) of the mercury found in fish muscle tissues occurred as methyl mercury (Table 3).

Table 4 shows Spearman's coefficients $\left(r_{S}\right)$ for the correlation between total mercury concentration and species total length.

Table 4. Spearman's correlation coefficients $\left(\mathrm{r}_{\mathrm{S}}\right)$ for total mercury concentrations and total lengths for the 8 species studied (correlations are significant at $\mathrm{p}<$ 0.05 ; ns: not significant)

\begin{tabular}{|llcc|}
\hline Species & \multicolumn{1}{c}{ Site } & $\mathrm{r}_{\mathrm{S}}$ & $\mathrm{p}$ \\
\hline Hydrolagus affinis & Lucky Strike & 0.94 & 0.002 \\
Hydrolagus pallidus & Lucky Strike & -0.22 & $\mathrm{~ns}$ \\
Synaphobranchus kaupi & Lucky Strike & 0.88 & 0.000 \\
& Menez Gwen/Lucky Strike & 0.41 & $\mathrm{~ns}$ \\
& Menez Gwen & 0.47 & 0.001 \\
Epigonus telescopus & Menez Gwen & 0.38 & $\mathrm{~ns}$ \\
Mora moro & Menez Gwen & 0.60 & 0.01 \\
Antimora rostrata & Rainbow & 0.60 & 0.03 \\
Deania calceus & Menez Gwen/Lucky Strike & 0.32 & $\mathrm{~ns}$ \\
& Menez Gwen & 0.52 & 0.03 \\
Etmopterus princeps & Lucky Strike & 0.62 & 0.000 \\
& Menez Gwen/Lucky Strike & 0.77 & 0.004 \\
\hline
\end{tabular}

\section{DISCUSSION}

Feeding behaviour probably constitutes the main cause of the variations in mercury concentrations among the species studied. Marques \& Porteiro (2000) observed in Hydrolagus affinis stomach contents 1 specimen of the hydrothermal mussel Bathymodiolus azoricus from the Lucky Strike vent field, showing that this species also feeds on vent species. B. azoricus has higher mercury concentrations than similar coastal species living in polluted environments (Martins et al. 2001). Therefore, the high amount of mercury found in $H$. affinis, close to that of the top predators analysed in this study, could be a result of predation on hydrothermal mussels. In addition, this predation may be the cause of the difference found in mercury concentrations in Hydrolagus spp.

Synaphobranchus kaupi is an active predator, with scavenge-feeding behaviour (Gordon \& Mauchline 1996). Because fish carcasses represent a large potential source of methyl mercury for aquatic scavengers (Sarica et al. 2005), the high mercury concentrations found in $S$. kaupi, in both tissues, could be a result of this species' diet.

Epigonus telescopus shows a mercury concentration close to that of the top predators, probably due to its diet, which is rich in fish (Tracey 1993). In general terms, an increase in the ratio of fish to invertebrates in the diet probably increases the intake of mercury (Gordon \& Duncan 1987). On the other hand, E. telescopus is a long-living species with slow growth, which could also explain the high accumulation of $\mathrm{Hg}$ in muscle tissue (Tracey 1993). In addition, the presence of this species in the hydrothermal vent area leads us to believe that some individuals may feed on local fauna, thus increasing potential for the bioaccumulation of mercury.

The Moridae, Mora moro and Antimora rostrata, presented mercury concentrations similar to those of the top predators, probably due to large-size prey (cephalopods and fishes) in their diet (Carrasón et al. 1997) and their patterns of slow growth (Magnússon 2001).

Top marine predators, like sharks, may contain high levels of mercury in their tissues, as a result of bioaccumulation up the food web (Lacerda et al. 2000); therefore, the high mercury concentrations found in the shark species Deania calceus and Etmopterus princeps were expected.

The difference in mercury concentrations in the muscle of these sharks, captured between Menez Gwen and 
Lucky Strike, may reflect a distinct bathymetric distribution and, consequently, different prey access (Clarke et al. 2002).

Methyl mercury is predominantly distributed in muscles, and, because of its lipophilic character, is not readily excreted; it accounts for up to $100 \%$ of the total mercury in fish muscle (Olsson et al. 1998). Our results show that methyl mercury represents $>80 \%$ of the total mercury in muscle of the species studied (Table 3). This is a common percentage for fish species, especially for top predators, as a consequence of the high bioavailability and retention of assimilated methyl mercury for long periods (Boening 2000). The higher methyl mercury concentrations accumulated in the muscle of Synaphobranchus kaupi (Table 3) may be related to the high fatty acid content in this tissue as has been described by Guerreiro et al. (2004).

In our study, when we compared the 2 analysed tissues, liver presented lower mercury concentrations than muscle, except in Synaphobranchus kaupi (Fig. 1).

Marine predators with scavenging behaviour have a greater potential to assimilate methyl mercury from deep-sea fish carcasses (Sarica et al. 2005); therefore, in addition to a low rate of metabolism and a low rate of mercury elimination, the concentrations found in the liver of Synaphobranchus kaupi could be a reflection of this species' diet and the manner in which it processes mercury.

Despite liver playing an important role in the detoxification of mercury, this metal may not ultimately be stored in this organ. Mercury may be taken up, detoxified by the liver and stored in other tissues (Mormede \& Davies 2001). Additionally, different fish species have different rates of metabolism and/or different rates of the elimination of metals (Hellou et al. 1992). The predominance of methyl mercury in fish muscle rather than in fat tissue, such as liver, indicates that accumulation is not controlled solely by lipid solubility (Mason et al. 1995). Hence, the low mercury concen- trations found in the liver of the studied species are presumably a reflection of these biochemical processes.

Animal size is also recognised to be of importance in determining the rate of the physiological processes that influence uptake, distribution and elimination of pollutants, such as mercury. The levels of this element in fish increase with body size, so larger, older fish have generally higher concentrations than smaller, younger fish (Storelli et al. 2002). In good agreement with the results reported in the literature for other marine fish (Anderson \& Depledge 1997, Mormed \& Davies 2001), a significant positive correlation between total length and total mercury concentrations was observed for the majority of species (Table 4).

Comparisons made with other deep-sea fish species, with identical diets, but caught in other areas (Table 5), demonstrate that the species analysed in the current study present higher mercury concentrations. However, the Azorean species analysed (Table 5) did not show significant differences when compared with the same species captured in a hydrothermal environment, probably reflecting similar feeding behaviour.

High concentrations of mercury were found by Carr et al. (1974) near the bottom of a rift valley at a depth of $3200 \mathrm{~m}_{i}$ this supports the hypothesis that mercury is introduced into the seawater column from actively spreading centres. Other studies conducted at the Mid-Atlantic Ridge further support this hypothesis (Rubin 1997, Geret et al. 2002). The mercury content injected by hydrothermal fluids in addition to the processes of mercury methylation (producing dimethyl mercury and monomethyl mercury) in deep waters (Mason et al. 1998) turn the surrounding environment into a very toxic place for organisms. Therefore, the fish species studied here are exposed to high levels of mercury, not only due to the bioavailability of toxic and stable forms of mercury in deep water, but also due to predation on organisms that have been exposed to this metal. We can assume from the present study that

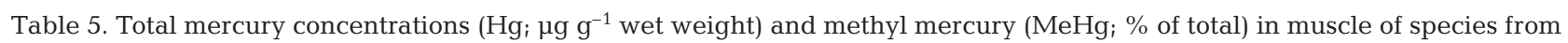
the present study and from other studies

\begin{tabular}{|llccccc|}
\hline Species & \multicolumn{1}{c}{$\begin{array}{c}\text { Common } \\
\text { name }\end{array}$} & $\begin{array}{c}\text { Sampling } \\
\text { location }\end{array}$ & $\begin{array}{c}\text { Size range } \\
(\mathrm{cm})\end{array}$ & $\begin{array}{c}\text { Range } \\
\mathrm{Hg}\end{array}$ & $\begin{array}{c}\text { Range } \\
\text { MeHg }\end{array}$ & Source \\
\hline Nematonurus armatus & Armed grenadier & Rockall Trough & - & $0.2-0.7$ & - & Cronin et al. (1998) \\
Lepidion eques & Large eye lepidion & Rockall Trough & $24-37$ & $0.04-0.4$ & - & Mormede \& Davies (2001) \\
Epigonus telescopus & Black cardinalfish & New Zealand & $47-71$ & $0.6-2.2$ & - & Tracey (1993) \\
& & Azores & $36.5-73$ & $0.3-2.2$ & - & Present study \\
Mora moro & Common mora & Azores & $37-60$ & $0.4-2.2$ & - & Present study \\
Prionace glauca & Blue shark & Azores & $97-210$ & $0.2-1.2$ & $85-94$ & Branco et al. (2004) \\
Thunnus alalunga & Albacore & Canary Island & $126-258$ & $0.2-1.8$ & $63-67$ & Branco et al. (2004) \\
& Azores & $87-117$ & $0.2-1.1$ & $86-97$ & Andersen \& Depledge (1997) \\
\hline
\end{tabular}


hydrothermal vents are an additional source of mercury for deep-sea fish species that are opportunistically associated with this environment.

These results are encouraging and warrant further research. For example, increasing the number of samples collected from each vent field, coupled with lipid and additional methyl mercury analyses would provide more accurate information on the significant difference between mercury accumulation in fish collected near vents and those collected elsewhere.

Acknowledgements. We thank the following people and organisations for their help and support during this study: the captain and crew of the research vessel 'Arquipélago'; the EU Framework Contract EC MAST 3-AMORES, EVK3-CT199900003 (VENTOX); the Portuguese Science Foundation funded program SEAHMA (FCT/PDCTM 1999/MAR/15281) and the pluriannual funding from the FCT for Research Unit No. 531. I.M. works under an FCT $\mathrm{PhD}$ fellowship (SFRH/BD/19736/2004).

\section{LITERATURE CITED}

Andersen JL, Depledge MH (1997) A survey of total mercury and methyl mercury in edible fish and invertebrates from Azorean waters. Mar Environ Res 44(3):331-350

Biscoito M, Ségonzac M, Almeida A, Desbruyéres D, Geistdoerfer P, Turnipseed M, Van Dover C (2003) Fishes from the hydrothermal vents and cold seeps - an update. Cah Biol Mar 43:359-362

Boening DW (2000) Ecological effects, transport, and fate of mercury: a general review. Chemosphere 40:1335-1351

Branco V, Canário J, Vale C, Raimundo J, Reis C (2004) Total and organic mercury concentrations in muscle tissue of the blue shark (Prionace glauca L., 1758) from the Northeast Atlantic. Mar Pollut Bull 49:854-874

Carr RA, Jones MM, Russ ER (1974) Anomalous mercury in near-bottom water of a Mid-Atlantic Rift valley. Nature 251:489-490

Carrasón M, Matallanas J, Casadevall M (1997) Feeding strategies of deep-water morids on the western Mediterranean slope. Deep-Sea Res A 44(9-10):1685-1699

Childress JJ, Fisher CR (1992) The biology of hydrothermal vent animals: physiology, biochemistry and autotrophic symbioses. Oceanogr Mar Biol Annu Rev 30:337-441

Clarke MW, Connolly PL, Bracken JJ (2002) Catch, discarding, age estimation, growth and maturity of the squalid shark Deania calceus west and north of Ireland. Fish Res 56:139-153

Cronin M, Davies MI, Newton A, Pirie JM, Graham T, Swan S (1998) Trace metal concentrations in deep-sea fish from the North Atlantic. Mar Environ Res 45(3):225-238

Gage JD, Tyler PA (1991) Deep-sea biology: a natural history of organisms at the deep-sea floor. Cambridge University Press

Geret F, Riso R, Sarradin PM, Caprais JC, Cosson R (2002) Metal bioaccumulation and storage forms in the shrimp, Rimicaris exoculata, from the Rainbow hydrothermal field (Mid-Atlantic Ridge), preliminary approach to the fluid-organism relationship. Cah Biol Mar 43:43-52

Gordon JDM (2001) Deep-water fisheries at the Atlantic Frontier. Cont Shelf Res 21(8-10):987-1003

Gordon JDM, Duncan JAR (1987) Aspects of the biology of Hoplostethus atlanticus and H. mediterraneus (Pisces:
Berycomorphi) from the slopes of the Rockall Trough and the Porcupine Sea Bright (northeastern Atlantic). J Mar Biol Assoc UK 67:119-133

Gordon JDM, Mauchline J (1996) The distribution and diet of the dominant, slope-dwelling eel, Synaphobrancus kaupi, of the Rockall trough. J Mar Biol Assoc UK 76:493-503

Guerreiro V, Narciso L, Almeida A, Biscoito M (2004) Fatty acid profiles of deep-sea fishes from the Lucky Strike and Menez Gwen hydrothermal vent fields (Mid-Atlantic Ridge). Cybium 28(1):33-44

Hellou J, Warren WG, Payne JF, Belkhode S, Lobel P (1992) Heavy metals and other elements in three tissues of cod, Gadus morhua, from the Northwest Atlantic. Mar Pollut Bull 24(9):452-458

Horvat M, May K, Stoeppler M, Byrne AR (1988) Comparative studies of methyl mercury determinations in biological and environment samples. Appl Organomet Chem 2: 515-524

Lacerda LD, Paraquetti HHM, Marins RV, Resende CE, Zalmon IR, Gomes MP, Farias V (2000) Mercury content in shark species from the south-eastern Brazilian Coast. Rev Bras Biol 60(4):571-576

Magnússon JV (2001) Distribution and some other biological parameters of two morid species Lepidion eques (Günther, 1887) and Antimora rostrata (Günther, 1878) in Icelandic waters. Fish Res 51:267-281

Marques A, Porteiro F (2000) Hydrothermal vent mussel Bathymodiolus sp. (Mollusca: Mytilidae): diet item of $\mathrm{Hy}-$ drolagus affinis (Pisces: Chimaeridae). Copeia 3:806-807

Martins I, Costa V, Porteiro F, Cravo A, Santos RS (2001) Mercury concentrations in invertebrates from Mid-Atlantic Ridge hydrothermal vent fields. J Mar Biol Assoc UK 81: 913-915

Mason RP, Reinfelder JR, Morel FMM (1995) Bioaccumulation of mercury and methylmercury. Water Air Soil Pollut 80: 915-921

Mason RP, Rolfhus KR, Fitzgerald WF (1998) Mercury in the North Atlantic. Mar Chem 61:37-53

Monteiro LR (1996) Seabirds as monitors of mercury contamination in the Portuguese Atlantic. PhD dissertation, University of Glasgow

Monteiro LR, Costa V, Furness RW, Santos RS (1996) Mercury concentrations in prey fish indicate enhanced bioaccumulation in mesopelagic environments. Mar Ecol Prog Ser 141:21-25

Mormede S, Davies IM (2001) Trace elements in deep-sea fish species from the Rockall Trough. Fish Res 5:197-206

Olsson PK, Kling P, Hogstrand C (1998) Mechanisms of heavy metal accumulation and toxicity in fish.. In: Langston WJ, Bebianno MJ (eds) Metal metabolism in aquatic environments. Chapman \& Hall, London, p 322-349

Rubin K (1997) Degassing of metals and metalloids from erupting seamount and mid-ocean ridge volcanoes: observations and predictions. Geochim Cosmochim Acta 61(17): 3525-3542

Saldanha L (1994) Fishes observed and collected during the Alvin dives at the Lucky Strike thermal vent site (MidAtlantic Ridge-1993). Cybium 18(4):460-462

Sarica J, Amyot M, Hare L, Blanchfield P, Bodaly RA, Hintelmann $\mathrm{H}$, Lucotte M (2005) Mercury transfer from fish carcasses to scavengers in boreal lakes: the use of stable isotopes of mercury. Environ Pollut 134(1):13-22

Storelli MM, Giacominelli-Stuffler R, Marcotrigiano GO (2002) Total and methylmercury residues in cartilaginous fish from Mediterranean Sea. Mar Pollut Bull 44:1354-1358

Tracey DM (1993) Mercury levels in black cardinalfish (Epigonus telescopus). NZ J Mar Freshw Res 27:177-181 